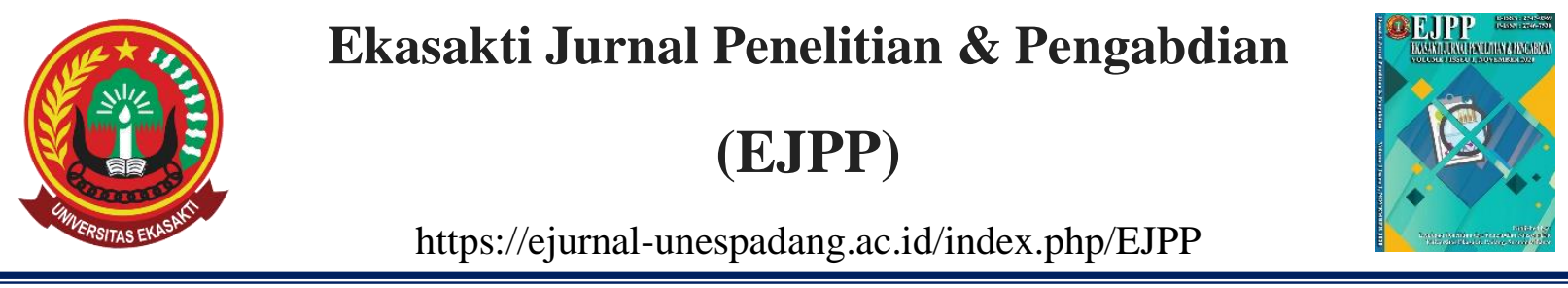

\title{
UPAYA PENINGKATAN HASIL BELAJAR FIKIH MELALUI SHARING DAN MEDIA AUDIO VISUAL PADA MATERI IMAN DAN HARI AKHIR SISWA KELAS IX DI MTSN 9 PESISIR SELATAN
}

\author{
$\operatorname{Erpan}^{1}$
}

1) MTsN 9 Pesisir Selatan, Tapan, Kab. Pesisir Selatan, Prov. Sumatera Barat. Email: Drs.Erpan@gmail.com

\section{INFO ARTIKEL}

Received : 21/10/2021

Revised : 01/11/2021

Publish : :10/11/2021

Kata Kunci:

Hasil Belajar, Iman pada Hari Akhir, Media Audio Visual, Teknik Sharing.

\begin{abstract}
ABSTRAK
Peranan metode dan teknik yang digunakan oleh guru memegang nilai strategis untuk keberhasilan pengajaran, sebab metode dan teknik adalah salah satu faktor yang sangat berperan dalam meningkatkan pengajaran Iman Pada Hari Akhir. Selama ini siswa kesulitan meningkatkan kemampuan dalam pembelajaran, karena pembelajaran yang dirasakan oleh siswa sangat membosankan apalagi ditambah materi yang diberikan cukup banyak dan diperlukan waktu yang lama untuk mempelajarinya terutama Iman Pada Hari Akhir. Tujuan penelitian ini adalah untuk meningkatkan hasil belajar siswa pada materi Iman pada Hari Akhir dengan menerapkan teknik Sharing dan Media Audio Visual. Sharing dan Media Audio Visual mengembangkan teknik belajar dengan men $\neg$ ggunakan media dengan menggunakan tiga kegiatan yaitu kegiatan membaca dan menulis materi Iman Pada Hari Akhir. Penelitian ini didesain melalui Penelitian Tindakan Kelas, menggunakan dua siklus. Hasil belajar siswa untuk siklus I 25 siswa $(71,4 \%)$ yang telah mencapai ketuntasan belajar dan masih terdapat 10 siswa $(28,6 \%)$ yang belum mencapai ketuntasan belajar dengan daya serap siswa mencapai 74,4\%. Pada siklus II meningkat menjadi 35 orang $(100 \%)$ yang mencapai ketuntasan dalam belajar dengan daya serap siswa 83,9\%. Melalui Sharing dan penggunaan media audio visual siswa dapat meningatkan hasil belajar siswa pada materi iman pada hari akhir.
\end{abstract}

Keywords:

Learning Outcomes, Faith in the Last Day, Audio Visual Media, Sharing Techniques.

\begin{abstract}
The role of methods and techniques used by teachers holds strategic value for teaching success, because methods and techniques are one of the most important factors in improving the teaching of Faith in the Last Days. So far, students have difficulty improving their learning abilities, because the learning felt by students is very boring, especially when the material provided is quite a lot and it takes a long time to learn, especially Faith in the Last Day. The purpose of this study was to improve student learning outcomes on the Faith material on the Last Day by applying Sharing techniques and Audio Visual Media. Sharing and Audio Visual Media develops learning techniques using media using three activities, namely reading and writing activities on Faith in the Last Days. This research was designed through Classroom Action Research, using two cycles. Student learning outcomes for the first cycle 25 students (71.4\%) who have achieved
\end{abstract}


mastery learning and there are still 10 students (28.6\%) who have not achieved learning mastery with student absorption reaching $74.4 \%$. In the second cycle increased to 35 people (100\%) who achieved mastery in learning with student absorption of $83.9 \%$. Through sharing and using audio-visual media, students can improve student learning outcomes on faith material on the final day.

\section{DOI: https://doi.org/10.31933/ejpp.v2i1.413}

\section{PENDAHULUAN}

Pendidikan merupakan upaya sadar yang dilakukan seseorang atau kelompok orang dalam usaha mendewasakan manusia melalui upaya pengajaran dan pelatihan (Jalius, Bayharti, and Andromeda 2013). Seseorang dapat melakukan sesuatu kegiatan dengan baik melalui proses belajar. Belajar dapat dikatakan sebagai suatu proses yang dilakukan seseorang untuk memperoleh bentuk perilaku baru yang relatif menetap (Jannah and Ellizar 2018).

Menurut (Wingkel 1991) belajar adalah; 'Suatu aktivitas mental/psikis, yang berlangsung dalam interaksi aktif dengan lingkungan, yang menghasilkan perubahan-perubahan dalam pengetahuan, pemahaman, keterampilan dan nilai sikap. Perubahan itu bersifat relatif konstan dan berbekas". Dengan demikian belajar merupakan proses interaksi antara seseorang dengan lingkungan yang melibatkan aktivitas mental/psikisnya sehingga terjadi perubahan tingkah laku baik pengetahuan, keterampilan maupun sikap ke arah yang lebih baik.

Berdasarkan uraian di atas diperoleh suatu pengertian bahwa belajar adalah proses yang kompleks. Dalam proses belajar, kegiatan pengalaman dan latihan menunjukkan adanya aktivitas belajar yang memiliki tujuan. Menurut (Hamdani 2011) pada prinsipnya tujuan belajar adalah sama yakni terbentuknya perubahan tingkah laku baik dari segi kognitif, afektif maupun psikomotor, namun dalam pencapaian tujuan tersebut dapat diterapkan teknik dan strategi yang berbeda-beda.

Tugas dan tanggung jawab utama dari seorang guru adalah menciptakan pembelajaran yang efektif, efisien, kreatif, dinamis, dan menyenangkan (Mulyasa 2009). Hal ini berimplikasi pada adanya kesadaran dan keterlibatan aktif antara dua subyek pembelajaran yaitu guru sebagai penginisiatif awal, pembimbing dan fasilitator dengan peserta didik sebagai orang yang mengalami dan terlibat aktif untuk memperoleh perubahan diri dalam pembelajaran itu sendiri.

Materi iman kepada hari akhir termasuk dalam aspek keimanan. Pada umumnya materi keimanan dipelajari siswa dengan cara mendengarkan ceramah guru. dari hasil diskusi dengan guru mata pelajaran yang mendapat tugas mengajar di kelas IX diperoleh informasi bahwa hasil belajar siswa dengan model pembelajaran seperti itu siswa yang terlibat aktif dalam kegiatan belajar ini hanya $40 \%$. Selain itu hasil tes formatif yang diberikan menunjukkan bahwa hanya $60 \%$ siswa yang tuntas dalam belajar dengan daya serap 65 .

Menghadapi kondisi seperti ini penulis tertarik untuk melakukan penelitian tindakan kelas untuk menemukan suatu cara atau teknik pembelajaran yang didukung oleh media pembelajaran sehingga siswa dapat terlibat secara aktif dan dapat meningkatkan hasil belajaranya. Menurut (Mayasri 2019), melalui Sharing dan Media Audio Visual pada materi iman pada hari akhir 
diharapkan siswa dapat memperoleh pengetahuan yang berkesan dan bermakna. Dengan demikian siswa akan lebih termotivasi untuk menerapkan pengetahuan tersebut dalam perilaku hidup sehari-hari. Penelitian ini bertujuan untuk meningkatkan hasil belajar siswa pada mata pelajaran Fiqih khususnya pada materi keimanan.

Salah satu model pembelajaran kooperatif yang dikembangkan adalah Think-pair-share. Tipe ini mula-mula dikembangkan oleh Frank Lyman pada tahun 1985. Cara ini efektif untuk mengubah pola diskursus di dalam kelas. Cara ini dapat pula memberi kesempatan bagi siswa untuk berfikir, menjawab dan saling membantu satu sama lainnya (Kurniawan, Elmunsyah, and Muladi 2018). Sharing yang dimaksudkan dalam penelitian ini menggunakan dasar-dasar pembelajaran kooperatif tipe think pair share,akan tetapi dalam rincian tahapan pembelajaran dimodifikasi sedemikian rupa sehingga lebih menekankan pada upaya sharing antar siswa baik yang dilakukan secara berpasangan maupun antar pasangan.

Pengajaran melalui audio visual adalah produksi penggunaan materi yang penyerapannya melalui pandangan dan pendengaran serta tidak seluruhnya tergantung pada pemahaman kata atau simbol-simbol serupa (Munir 2017). Dale dalam (Sudjana 2009) memperkirakan perolehan hasil belajar melalui indera pandang berkisar $75 \%$, melalui indera dengar $13 \%$ dan melalui indera lainnya $12 \%$. Dengan demikian dapat disimpulkan bahwa media audio visual adalah media yang dapat digunakan untuk menyampaikan pesan-pesan pembelajaran yang dapat melibatkan indra pandang dan indra pendengaran dari peserta didik yang bertujuan untuk mendorong terciptanya proses belajara pada peserta didik.

\section{METODE PENELITIAN}

Penelitian ini merupakan suatu penelitian tindakan kelas yang dilaksanakan di MTSN 9 Pesisir Selatan dengan jumlah siswa 35 orang, yang terdiri dari siswa laki-laki 17 orang dan siswa perempuan 18 orang. Penelitian ini didasarkan atas pertimbangan bahwa prestasi siswa belum optimal. Hal ini nampak pada perolehan nilai rata-rata siswa di kelas ini relatif masih rendah.

Penelitian tindakan kelas ini dilaksanakan dengan alokasi waktu 4 jam pelajaran, 2 kali pertemuan dan dilaksanakan dalam 2 siklus. Apabila pada siklus I belum memperlihatkan hasil sebagaimana yang diharapkan, maka akan dilanjutkan pada siklus berikutnya (siklus II). Tindakan pada siklus II merupakan perbaikan dan penyempurnaan dari tindakan yang dilaksanakan pada siklus I. Oleh karena itu tindakan siklus II dilakukan dengan melihat hasil pengamatan kegiatan belajar mengajar serta hasil belajar siswa pada siklus I.

Penelitian ini dilaksanakan melalui empat tahapan, yaitu 1) tahap persiapan, yang dimulai dengan membuat jadwal penelitian, melakukan diskusi dengan teman sejawat, guru mitra dan semua pihak yang membantu dalam pelaksanaan tindakan, menyusun Rencana Pelaksanaan Pembelajaran (RPP), membuat lembar observasi yang digunakan dalam pengamatan proses belajar mengajar, menetapkan alat bantu dan sumber belajar yang relevan dengan materi pelajaran, dan merancang alat evaluasi untuk melihat penguasaan materi pembelajaran sekaligus hasil belajar siswa; 2) tahap pelaksanaan tindakan, yaitu mengkondisikan siswa untuk siap belajar. Guru menyampaikan kompetensi yang harus dicapai oleh siswa dan melakukan 
apersepsi. Pelaksanaan tindakan dilakukan di dalam kelas pada saat membaca dan menelaah informasi serta mengisi lembaran kerja, penggunaan media audio visual melalui penayangan film Dunia Fana (Produksi Ahad-Net) dan tayangan video karya Muh.Ahsan; 3) tahap observasi dan evaluasi, yaitu guru memantau situasi aktivitas siswa dalam proses pembelajaran dan pelaksanaan kegiatan belajar mengajar melalui lembar observasi, dan guru memberikan evaluasi melalui soalsoal uraian; 4) tahap analisis data, yaitu melaksanakan analisis dan refleksi terhadap hasil penilaian dan pengamatan Jika pada siklus I belum memberikan hasil yang diharapkan maka dilanjutkan ke siklus II.

Data penelitian ini diperoleh melalui observasi dan tes kognitif. Hasil tes kognitif yang diperoleh melalui tes akhir dianalisis secara deskriptif untuk mengetahui pencapaian kriteria ketuntasan belajar minimal (KKM), sedangkan hasil pengamatan (observasi) dianalisis secara deskriptif untuk mengetahui situasi pembelajaran. Menurut (Sugiyono 2012) Observasi untuk mengetahui situasi dan aktivitas siswa dalam melakukan aktivitas belajar melalui sharing dan penggunaan media audio visual dan pelaksanaan kegiatan belajar mengajar. Tes kognitif digunakan untuk mengetahui kemampuan siswa dalam menguasai materi.

\section{HASIL DAN PEMBAHASAN}

Dalam penelitian tindakan kelas ini ditetapkan indikator kompetensi yang harus dikuasai oleh siswa terkait dengan materi iman pada hari akhir. Indikator kompetensi yang dimaksud adalah:

1. Kemampuan memberi makna tentang hari akhir;

2. Kemampuan dalam menguraikan proses kejadian hari akhir;

3. Kemampuan dalam mengungkap hikmah beriman kepada hari akhir.

Setiap akhir siklus dilakukan evaluasi untuk mengetahui hasil belajar siswa, dan dalam pelaksanaan tindakan disiapkan rencana pembelajaran yang sesuai dengan tahapan teknik yang dipilih. Kegiatan siklus I dilaksanakan melalui rencana pembelajaran dengan alokasi waktu kegiatan belajar mengajar 2 jam pelajaran. Siklus I diawali dengan pemberian motivasi, penjajakan awal, dan penyiapan kondisi siswa untuk belajar. Selanjutnya siswa membaca dan menelaah informasi terkait dengan iman ada hari akhir. Setelah itu siswa mengidentifikasi hal-hal penting yang harus dipahami. Adapun hasil belajar siswa yang diperoleh setelah dilakukan evaluasi pada akhir pelajaran dapat dilihat pada tabel berikut ini.

Tabel 1. Data Hasil Belajar Siswa Siklus I

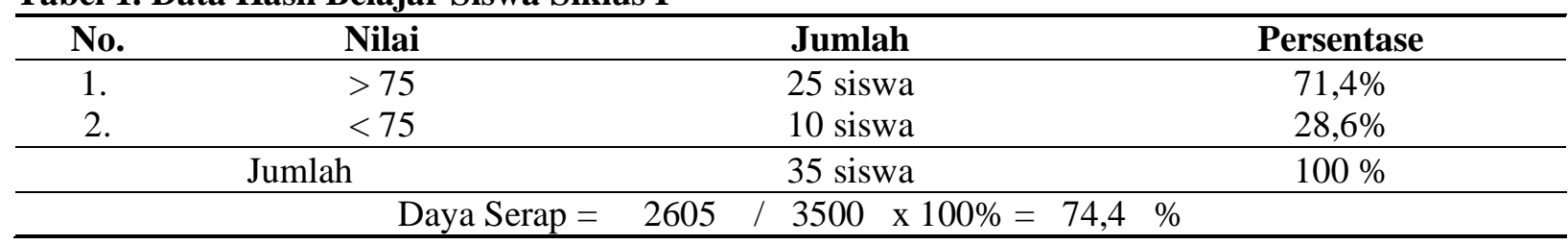

Dari tabel ini dapat dilihat 25 siswa $(71,4 \%)$ yang telah mencapai ketuntasan belajar dan masih terdapat 10 siswa $(28,6 \%)$ yang belum mencapai ketuntasan belajar. Selain itu daya serap siswa mencapai $74,4 \%$. Untuk mengetahui pelaksanaan kegiatan belajar mengajar melalui Sharing 
dan Media Audio Visual digunakan digunakan lembar pengamatan guru dan siswa. Dari hasil observasi yang diperoleh data sebagai berikut.

Tabel 2. Data Hasil Pengamatan KBM

\begin{tabular}{|c|c|c|c|}
\hline No. & Kriteria & Jumlah Aspek & Persentase \\
\hline 1. & Baik & 10 & $71.42 \%$ \\
\hline 2. & Cukup & 4 & $28.57 \%$ \\
\hline 3. & Kurang Baik & & \\
\hline 4. & Sangat Tidak Baik & & \\
\hline
\end{tabular}

Berdasarkan hasil obesrvasi aktivitas siswa, aspek-aspek pada kegiatan belajar mengajar dan hasil belajar siswa ternyata masih perlu ditingkatkan dalam rangka mencapai kriteria keberhasilan tindakan yang telah ditetapkan. Pada kegiatan siklus II ini guru mengawali kegiatan belajar dengan cara memotivasi siswa melalui penyampaian pentingnya penerapan iman kepada hari akhir. Kegiatan inti pembelajaran lebih diarahkan pada upaya untuk memperbaiki kegiatan pada siklus I dengan cara menayangkan video pembelajaran tentang Iman Pada Hari Akhir (karya Muh.Ahsan). Setelah itu siswa mengerjakan tugas pada lembar kerja dan melakukan sharing bersama teman (pasangannya). Adapun hasil belajar siswa yang diperoleh setelah dilakukan evaluasi pada akhir pelajaran dapat dilihat pada tabel berikut ini.

Tabel 3. Data Hasil Belajar Siswa Siklus II

\begin{tabular}{cccc}
\hline No. & Nilai & Jumlah & Persentase \\
\hline 1. & $>75$ & 35 siswa & $100 \%$ \\
2. & $<75$ & - & $0 \%$ \\
& Jumlah & 35 siswa & $100 \%$ \\
\hline
\end{tabular}

Daya Serap $=2935 / 3500 \times 100 \%=83,9 \%$

Berdasarkan tabel di atas jelas bahwa jumlah siswa yang mencapai ketuntasan belajar adalah 35 orang (100\%). Daya serap siswa pada evaluasi hasil belajar ini mencapai 83,9\%. Untuk mengetahui aktivitas siswa pada pelaksanaan kegiatan belajar pada siklus II, peneliti mengggunakan lembar observasi.

Berdasarkan pengamatan yang dilakukan terdapat 32 orang siswa $(91,4 \%)$ yang aktif dalam belajar pada saat penayangan media audio visual dan mengerjakan tugas. Untuk mengetahui pelaksanaan kegiatan belajar mengajar melalui Sharing dan Media Audio Visual digunakan digunakan lembar pengamatan guru dan siswa. Dari hasil observasi diperoleh data sebagai berikut. 
Tabel 4. Data Hasil Pengamatan KBM

\begin{tabular}{cccc}
\hline No. & Kriteria & Jumlah Aspek & Persentase \\
\hline 1 & Baik & 12 & 85.71 \\
2 & Cukup & 2 & 14.28 \\
3 & Kurang Baik & & \\
4 & Sangat Tidak Baik & & \\
\hline
\end{tabular}

Berdasarkan hasil pengamatan pada aspek kegiatan belajar mengajar, hasil belajar siswa yang diperoleh dari hasil evaluasi melalui tes tertulis pada akhir pelajaran memperlihatkan peningkatan keberhasilan. Hal ini terbukti pada kegiatan pembelajaran siklus II, siswa yang berpartisipasi aktif dalam pembelajaran mencapai $91,4 \%$.

Selain itu daya serap hasil belajar siswa yang diperoleh melalui evaluasi tes akhir pelajaran meningkat pula menjadi $83,9 \%$ dengan persentasi siswa yang tuntas mencapai Kriteria Ketuntasan Belajar minimal mencapai 100\%. Pengamatan tentang kegiatan belajar mengajar pada siklus I 10 aspek (71.42\%) yang memperoleh kriteria baik dan 4 aspek (28.57\%) yang memperoleh kriteria cukup. Pada siklus kedua meningkat menjadi 12 aspek $(85.71 \%)$.

Peningkatan hasil belajar siswa untuk menguasai kompetensi keimanan kepada hari akhir nampak setelah membandingkan hasil penelitian yang dicapai pada siklus I dan II, baik dari segi aktivitas siswa maupun aktivitas guru selama pelaksanaan pembelajaran, evaluasi hasil belajar siswa melalui tes tertulis pada akhir pelajaran serta respon siswa tentang proses pembelajaran itu sendiri. Peningkatan hasil belajar siswa ini berkaitan erat dengan modifikasi langkah-langkah pembelajaran yang dilaksanakan oleh siswa.

Dalam hal ini siswa termotivasi untuk mengerahkan seluruh aktivitas mentalnya, memusatkan perhatiannya (konsentrasi), agar dapat menemukan dan mengidentifikasi hal-hal pokok/penting dari materi atau bahan ajar. Untuk selanjutnya siswa lebih mempermantap pemahamannya tentang materi dengan mengajarkan atau saling membagi antar satu dengan yang lain. Pemahaman materi lebih ditingkatkan lagi melalui penggunaan media audio visual dalam bentuk Film yang ditayangkan melalui VCD.

Sehingga siswa bukan hanya sekedar menguasai secara kognitif materi keimanan kepada hari akhir, akan tetapi memberi kesan yang lebih mendalam bagi pembentukan sikap dan perilaku hidupnya sehari-hari. Untuk lebih mengoptimalkan kegiatan pembelajaran dengan model belajar sharing yang dikolaborasikan dengan penggunaan media audio visual sangat membutuhkan keahlian dan kepiawaian guru, baik dalam hal pengaturan efisisensi waktu, pengeloalaan kelas, maupun dalam penggunaan perangkat pendukung.

Meskipun hasil belajar siswa melalui model belajar sharing yang dikolaborasikan dengan penggunaan media audio visual namun masih perlu pengembangan lebih lanjut. Hal ini berdasarkan hasil pengamatan pada kegiatan belajar mengajar yang menunjukkan ada beberapa siswa yang hanya memperhatikan tayangan gambar tapi kurang memperhatikan narasi lisan maupun yang tertulis.

Berdasarkan pengamatan hasil belajar siswa yang diperoleh dari hasil tes tertulis $71,4 \%$. yang tuntas. Sedangkan daya serap siswa adalah 74,4\%. Di samping itu masih terdapat 10 orang 
siswa 28,6\% yang belum tuntas Sehingga dengan melihat kenyataan ini diperlukan tindakan lebih lanjut karena belum mencapai kriteria keberhasilan siswa dalam belajar. Pada siklus I terdapat beberapa kelemahan dalam proses pembelajaran. Hal ini tampak dalam hal-hal seperti siswa belum termotivasi untuk segera menyelesaikan tugas pada lembar kerja berpasangan. Ada siswa yang enggan untuk mengerjakan tugas bersama pasangannya, sehingga estimasi waktu yang telah ditetapkan oleh guru tersita untuk mengarahkan dan membimbing siswa supaya dapat bekerja bersama pasangannya.

Berdasarkan kelemahan-kelemahan pada uraian di atas dilaksanakan langkah-langkah perbaikan pada siklus II yaitu:

a. Guru memberikan motivasi kepada seluruh siswa tentang tujuan pokok mempelajari materi iman kepada hari akhir semata-mata demi keselamatan hidup dunia dan akhirat, menjelaskan langkah-langkah kegiatan yang akan dilakukan, memberi kesempatan untuk mempelajari dan memahami materi melalui kerja berpasangan, serta melakukan kompetisi antar pasangan dalam hal menyelesaikan tugas pada lembar kerja;

b. Alokasi waktu untuk menyelesaikan setiap tahapan kegiatan disampaikan kepada siswa sehingga siswa memiliki target waktu untuk menyelesaikan tugas;

c. Tampilan pesan disajikan pada awal dan akhir pembelajaran melalui media audio visual, serta kegiatan pembelajaran dilakukan di ruang laboratorium computer;

d. Dengan pengaturan waktu yang tepat, guru memiliki waktu yang cukup untuk memberikan penekanan khusus pada siswa untuk memberikan penekanan khusus pada materi inti yaitu dengan cara menugaskan siswa untuk membaca sambil meresapi makna dalil naqli yang berkaitan dengan hari akhir yang terdapat pada Al-Qur'an maupun hadis.

Setelah dilakukan tindakan perbaikan melalui langkah-langkah perbaikan sebagaimana pada uraian sebelumnya, maka pada siklus II terjadi peningkatan pada situasi pembelajaran dan hasil belajar siswa baik pada proses pembelajaran maupun akhir pelajaran. Maka pada siklus II terjadi peningkatan pada situasi pembelajaran dan hasil belajar siswa baik pada proses pembelajaran maupun akhir pelajaran yaitu:

1) Hasil belajar yang diperoleh siswa melalu tes tertulis pada akhir pelajaran untuk siklus I terdapat 25 siswa $(71,4 \%)$ yang telah mencapai ketuntasan belajar dan masih terdapat 10 siswa $(28,6 \%)$ yang belum mencapai ketuntasan belajar dengan daya serap siswa mencapai $74,4 \%$. Pada siklus II terjadi peningkatan menjadi 35 orang (100\%) yang mencapai ketuntasan dalam belajar dengan daya serap siswa mencapai 83,9\%;

2) Pengamatan tentang aktivitas siswa dalam pelaksanaan pembelajaran pada siklus I 25 siswa $(71.42 \%)$ yang aktif dan 10 siswa $(28,6 \%)$ yang cukup aktif. Pada siklus kedua siswa yang aktif meningkat menjadi 32 orang $(91,4 \%)$. Pengamatan tentang kegiatan belajar mengajar pada siklus I 10 aspek (71.42\%) yang memperoleh kriteria baik dan 4 aspek (28.57\%) yang memperoleh kriteria cukup. Pada siklus kedua meningkat menjadi 12 aspek (85.71\%).

Berdasarkan hasil penelitian dan pembahasan yang dilakukan, jelaslah bahwa melalui 
sharing dan penggunaan media audio visual pada mata pelajaran Fiqih untuk materi iman kepada hari akhir siswa mengalami peningkatan pada hasil belajar. Demikian pula pada pelaksanaan pembelajaran terjadi peningkatan. Dengan demikian hipotesis yang telah dirumuskan dalam penelitian ini dapat dibuktikan yaitu; "Dengan Melalui Sharing Dan Penggunaan Media Audio Visual Pada Materi Iman Kepada Hari Akhir,Maka Hasil Belajar Siswa Akan Meningkat”.

\section{KESIMPULAN}

Berdasarkan hasil penelitian diperoleh kesimpulan bahwa hasil belajar siswa yang tercapai dan diperoleh siswa dari evaluasi tes tertulis pada akhir pembelajaran mengalami peningkatan, untuk siklus I 25 siswa $(71,4 \%)$ yang telah mencapai ketuntasan belajar dan masih terdapat 10 siswa $(28,6 \%)$ yang belum mencapai ketuntasan belajar dengan daya serap siswa mencapai $74,4 \%$. Pada siklus II terjadi peningkatan menjadi 35 orang (100\%) yang mencapai ketuntasan dalam belajar dengan daya serap siswa mencapai 83,9\%.

Pengamatan tentang aktivitas siswa dalam pelaksanaan pembelajaran pada siklus I,25 siswa $(71.42 \%)$ yang aktif dan 10 siswa $(28,6 \%)$ yang cukup aktif. Pada siklus kedua siswa yang aktif meningkat menjadi 32 orang $(91,4 \%)$. Pengamatan tentang kegiatan belajar mengajar pada siklus I, 10 aspek (71.42\%) yang memperoleh kriteria baik dan 4 aspek (28.57\%) yang memperoleh kriteria cukup. Pada siklus kedua meningkat menjadi 12 aspek (85.71\%). Melalui Sharing dan penggunaan media audio visual siswa dapat mencapai ketuntasan belajar pada materi iman pada hari akhir.

Untuk mengoptimalkan pencapaian hasil pembelajaran pada mata pelajaran Fikih guru hendaknya mempertimbangkan kebermaknaan dari proses belajar itu sendiri. Pembelajaran lebih bermakna apa bila siswa termotivasi terlibat secara aktif, mandiri, dan dapat membina kebersamaan dalam rangka menerapkan pengetahuan yang dimiliki dalam konteks kehidupan sehari-hari. Selain itu, penggunaan media yang tepat dan menarik, pengalokasian waktu dan pengorganisasian siswa perlu diperhatikan dalam rangka efisiensi dan efektifitas pencapaian hasil belajar siswa. Dan terakhir, Penelitian Tindakan Kelas ini diharapkan dapat menjadi bahan informasi bagi guru khususnya guru Fikih agar dapat melakukan inovasi dalam pembelajaran, baik dalam bentuk strategi belajar maupun penciptaan media pembelajaran yang menunjang proses belajar mengajar.

\section{REFERENSI}

Hamdani. 2011. Strategi Belajar Mengajar. Bandung: CV Pustaka Setia.

Jalius, Ellizar, Bayharti, and Andromeda. 2013. "Pengaruh Motivasi Dan Pembelajaran Kimia Menggunakan Modul Dan Tanpa Modul Terhadap Hasil Belajar Kimia Di RSMA- BI." Prosiding Semirata FMIPA Universitas Lampung 117-24. 
Jannah, Wardhatul, and Ellizar. 2018. "Validitas Dan Praktikalitas Modul Larutan Penyangga Berbasis Pendekatan Saintifik Dengan Menerapkan Teknik Probing Prompting Untuk Kelas XI SMA/MA.” Menara Ilmu XII(12):101-11.

Kurniawan, Hafizd Rizky, Hakkun Elmunsyah, and Muladi. 2018. "Perbandingan Penerapan Model Pembelajaran Project Based Learning Dan Think Pair Share Berbantuan Modul Ajar Terhadap Kemandirian Dan Hasil Belajar Siswa Kelas XI Di SMKN 3 Malang.” Jurnal Pendidikan 3(2):80-85.

Mayasri, Hani Nur. 2019. "Efektivitas Model Pembelajaran Kooperati.” Hipotenusa : Journal of Mathematical Society 1(1).

Mulyasa, E. 2009. Kurikulum Berbasis Kompetensi. Bandung: Rosda Karya Nana.

Munir. 2017. Pembelajaran Digital. Bandung: Alfabeta.

Sudjana. 2009. Media Pengajaran. Bandung: Remaja Rosdakarya.

Sugiyono. 2012. Metode Penelitian Kuantitatif, Kualitatif Dan R\&D. Bandung: Alfabeta.

Wingkel, W... 1991. Psikologi Pengajaran. Jakarta: Grasindo. 